\title{
GENDER PERSPECTIVE CONCERNING THE BASIC MATHEMATICAL ABILITIES
}

\author{
Rosalia Indriyati Saptatiningsih \\ (Program Studi Pendidikan Pancasila dan Kewarganegaraan/Universitas PGRI \\ Yogyakarta/Indonesia/iin@upy.ac.id)
}

Padrul Jana

(Program Studi Pendidikan Matematika/Universitas PGRI

Yogyakarta/Indonesia/+6285295579152/padrul.jana@upy.ac.id)

\begin{abstract}
This research aims at mapping the basic mathematical abilities of the students of Civics Education. Then, the existence of differences regarding this basic skill would be scientifically studied from the perspective of gender. The combination of qualitative and quantitative (Mixed Methods) would be employed as the research method, the qualitative would be used to map the basic mathematical abilities and the quantitative is for testing the quality of instrument which would be used from the perspective of gender. The results are (1) civic education students' ability on visualization is higher than mathematical logic. (2) Based on gender, it indicates that, based on the given 30 questions, women gain 17,85 questions and men 14,4 questions of correct answers. (3) The test to determine the mathematical basic abilities indicates the output Independent Samples Test Test value Asymp. Sig. (2-tailed) $=0,008<0,05$. Meaning that H0 reveals the fact that man and woman possess different levels of abilities.
\end{abstract}

Keywords: Basic Mathematics, Gender, Perspective.

\section{Introduction}

The basic mathematical ability is an important competency that should be mastered by all university graduates [1]. Mathematical literacy is the ability to formulate problems, apply and interpret the mathematical problems more contextually [2]-[5]. The abilities to do the basic calculation, analyze and solve the problems become the elements to measure one's basic abilities [6]. On many occasions, it is used as a tool to measure one's ability academically. Various purposes such as civil servant test, undergraduate and post graduated admission test and other private institutions. The reason for this is that the basic mathematical abilities, which have more portions on the academic potential test, can be used as one of the parameters to determine one's successfulness and readiness to do the duties or continue the next higher level of education [7].

Considering the importance of basic mathematical abilities that becomes one of the parameters in the academically potential test with all the benefits, attracts the researchers' interest to pick this theme of the research. It makes this research entitled to mapping the basic mathematical abilities on the students of Civics from the perspective of gender would be relevant. According to Fazlurrachman in [8], gender is defined by the social experts to explain the differences of sex on humans and their characteristics as the God creations and also the output of citizens' culture/habit which have been constructed, learned and socialized.

The existence of this differentiating possesses an urgent position because many parties mix/blend the human's natural characteristics that cannot be changed, with the artificial 
characteristics that still can be changed. Even our society tends to have difficulty in differentiating between the sexes as the natural with the gender. The term of gender comes from the Latin language, originally 'genus', possesses the meaning of characteristics or kinds. Gender is the characteristics and the behaviors that are attached to humans, both to man and woman, formed through local social and culture [9]. Because gender comes from social and culture around, it would not be permanent and makes it would be different from one place to another. For example, a chef was identified as a woman's activity, but now many famous ones are men.

Why it should be the students of civic education for these research objects? One of the main reasons is that, based on the PANRB regulation 2018, the selection of basic abilities consists of Nationally Knowledge Test (TWK), General Intelligence Test (TIU), and Personal Character Test (TKP). They make it appropriate for the researchers to pick the students of Civics educations as the subjects of mapping the basic mathematical abilities. The students of this department are equipped with the knowledge of in depth-archipelago concepts comprehensively. Two aspects that are measured by the Ministry of Administrative and Bureaucratic Reform have been fulfilled, another one aspect depends on the student's characteristics.

The novelty of this research relies on the perspective of gender. Why is it so? The first reason is the mapping has been conducted by separating the sexes of the students, for the sake of gaining the representative information. Second, giving information regarding basic mathematical abilities should be done since it enables us to measure the detailed aspects. This information needs to be follow up. Third, by employing the gender perspective, there are three main pieces of information gaining from this research, those are the mapping of basic mathematical abilities generally, sexes based and the comparison of mathematical abilities based on gender perspective.

\section{Methodology}

\subsection{Research Kinds}

This research employs Mixed Methods. The scope of this research employs quantitative and qualitative in the same research. The qualitative method is used to map the basic mathematical abilities using the result of the mathematical basic abilities, interview, and documentation gained from the students. The method of quantitative is used to measure the different abilities from the perspective of gender.

\subsection{Research Instrument and the Analysis}

A research instrument is a tool used in the process of gaining data. For the research of Mathematic education, the research instrument is used to measure the mathematic abilities [10]. The instruments being used in this research are:

\section{Test Questions}

The instrument test is used to measure the basic mathematical abilities for the students of civics education. This is multiple choices, conducted on everybody based on the gender perspectives and this is closed. The gained data would be processed and analyzed to map and reveal the students' mathematical abilities.

\section{Interview}

It is used to confirm and complete the data on test results about basic mathematical abilities. The result of the interview will strengthen the information data which would be used to map the students' basic mathematical abilities. The interview was conducted with all men and women respectfully and randomly. 
The instrument analysis being employed is validity testing, both from the experts and from the statistic. The technique used to test the validity uses the correlation coefficient formula of the product-moment Pearson. This is valid whenever sig. (2-tailed) < alpha which is 5\% used, or the table below can be referred [10]:

Table 1 Criteria of Correlation Coefficient of Instrument Validity

\begin{tabular}{lll}
\hline Coefficient of Correlation & Correlation & Validity Interpretation \\
\hline $0,90 \leq \mathrm{r}_{\mathrm{xy}} \leq 1,00$ & Very high & Very proper/ very good \\
$0,70 \leq \mathrm{r}_{\mathrm{xy}}<0,90$ & High & proper/ good \\
$0,40 \leq \mathrm{r}_{\mathrm{xy}}<0,70$ & Medium & Fairly proper/ Fairly good \\
$0,20 \leq \mathrm{r}_{\mathrm{xy}}<0,40$ & Low & Not proper/ bad \\
$\mathrm{r}_{\mathrm{xy}}<0,20$ & Very low & Very not proper/Very bad \\
\hline
\end{tabular}

Then, the instrument's reliability would be tested. It functions to measure instrument consistency. The high and low instrument is based on the value of the correlation coefficient among questions that use $r$ notation. The criteria refer to:

Table 2 Coefficient Criteria of Instrument Reliability

\begin{tabular}{lll}
\hline Coefficient Correlation & Correlation & Validity Interpretation \\
\hline $0,90 \leq \mathrm{rxy} \leq 1,00$ & Very high & Very proper/ very good \\
$0,70 \leq \mathrm{rxy}<0,90$ & High & proper/ good \\
$0,40 \leq \mathrm{rxy}<0,70$ & Medium & Fairly proper/ Fairly good \\
$0,20 \leq \mathrm{rxy}<0,40$ & Low & Not proper/ bad \\
$\mathrm{rxy}<0,20$ & Very low & Very not proper/Very bad \\
\hline
\end{tabular}

\subsection{Data Analysis Technique \\ First Data Analysis}

The beginning data testing uses the classic assumption test, those are homogeneity and normality test. Kolmogorov-Smirnov was employed to test the normality, functioning to determine whether it employs parametric or non-parametric statistics. Next is the homogeneity, to determine and measure the diversity of the tested instruments to the respondents. This test uses the Levene Test.

\section{Qualitative Data Analysis}

This technique is employed to answer the first and second research problems by employing the triangulation method that is the combination of the test results, interview, and questionnaires. The result will confirm the mapping of the basic mathematical abilities of the civics students. This triangulation is expected to gain complete and comprehensive data purely based on the fields.

\section{Quantitative Data Analysis}

The quantitative data analysis is used to answer the third research problem, using the $t$ test as the comparative test to reveal the existence of differences in the two tested groups.

\section{Results}

\subsection{Instrument Validity Test}

Based on the result of instrument validity analysis towards 35 questions, the questions of $3,7,18,19$ and 33 are not valid. This makes 30 questions are valid based on reliability tests.

\subsection{Instrument Reliability Analysis}

This test was conducted by comparing the alpha Cronbach by referring rules in table 2 . Based on the output of SPSS 23, it gains: 


\begin{tabular}{cc}
\multicolumn{2}{c}{ Table 3 Reliability Test Result } \\
Reliability Statistics \\
\hline Cronbach's Alpha & N of Items \\
, 748 & 30 \\
\hline
\end{tabular}

From the result of statistical reliability, it gains the Cronbach Alpha 0,748. Based on table 2, it is categorized as high, meaning that the test instrument fulfills the reliability requirement.

\subsection{Normality dan Homogeneity Test Analysis}

Based on the data calculation using SPSS, it gains output One-Sample KolmogorovSmirnov Test value of Asymp. Sig. (2-tailed) = 0,200 > 0,05, meaning that H0 possesses the normal distribution of the data. Based on the data calculation using SPSS, it gains the output Test of Homogeneity of Variances Test value of Asymp. Sig. (2-tailed) = 0,673 > 0,05 meaning that $\mathrm{H} 0$ possesses the homogeneity on basic mathematical abilities between men and women.

\subsection{Mapping the Basic Mathematics Abilities of the Civics Students}

The profile of Civics students on basic mathematical abilities, among 30 questions, has revealed to us that the highest is 28 and the lowest is 5 . The average correct answer is 16,3 with a 5,5 deviation standard. Moreover, 50\% are correct on the series tests, arithmetic, comparison test, and logic. All of these are included in the mathematic ability test and logic. By in-depth consideration, from all aspects, it gains us that $71 \%$ answer correctly, $48 \%$ of social arithmetic, $46 \%$ of comparison test and $31 \%$ of logic.

The map of basic mathematical abilities of civics students on the test of visual, reveals $54 \%$ are correct consisting of pattern sustainable test, arrange the form and classify the pictures. If it is observed, 59\% are correct on pattern sustainable, $29 \%$ are correct on form arrangement and $88 \%$ are correct on picture classification.

\subsection{Mapping the Students' Basic Mathematical Abilities from the Perspective of Gender.}

In this $\mathrm{Y}, \mathrm{Z}$ and Millenium era, a woman has almost the same position as man, in many government and private institutions. The education quality for women has been well established, it accommodates a woman in the concept of development. However, on some occasions, there are perspectives that man has the position as the first gender and woman is the second one. It becomes an obstacle for a woman to work [9]. It also affects the process of mathematical learning; there is space between man and woman. There is labeling that the man only that can learn mathematics to achieve good carrier. In accordance with [11] statement, some people still consider that Mathematics is only for men, the woman will get the other subjects. The result of TIMSS in 1989 explained to us that spatial problem will end differently between man and woman. That perspective is different from what the researchers have found through this research that can be described as follows:

In this part, the basic mathematical abilities would be mapped based on the perspective of gender. There are 30 respondents of men and 35 of women would make them 65 students. Based on the test result, it indicates that women get a higher score of 18,17 higher than the man of 14,4 from 30. The highest score for men is 28 and the lowest is 5, and women get the higher is 26 and the lowest is 9. From the perspective of range between man and woman, there is $23 ; 17$. The women have 4,8 deviation standard and men have 5,8, meaning that women students of correct answers tend to be prevalent than the men students. 
It indicates that the ability to think logic on women is better than the men; it proves that the perspective that says Mathematics is for men is no longer relevant for now. The result of this research argued that women tend to use feelings to solve problems compared to men. This research supports the women are more diligent and patient. This reflects the result of the mathematical test for the students of Civics.

\subsection{Test on Different Abilities on Basic Mathematics}

Based od the data calculation using SPSS, it gains the output Independent Samples Test Test value of Asymp. Sig. (2-tailed) $=0,008<0,05$. Meaning that basic abilities on man and woman are different.

\section{Discussion}

An in-depth discussion of the findings of this study has implications for what factors cause the ability of men and women to differ. one possibility is the variable family background, parenting education, and the environment. this can be a debate and further research with more interesting topics.

\section{Conclusions}

From a series of research that has been conducted which are included instrument arrangement, instrument validation, instrument validation, data gaining, data process, it can be concluded that: Civics education student profile on basic mathematical abilities on a subtest of visual abilities is higher than the subtest of mathematics and logic. There are $51 \%$ of respondents can answer correctly on visual and $49 \%$ on logic. It reveals to us that the students of Civics are more able to solve the problems on picture patterns, arrange forms and picture classification compared to solve the problems on calculations. Based on the profile of the students of civics towards the gender perspective, there are 17,85 of women able to provide correct answers and 14,4 of men. It is clear that women are better at basic mathematical solving problems. If we consider more carefully, men are only better on form arrangement (only one aspect), women are better in five aspects those are series of numbering, arithmetic, comparison, logic, pattern sustainable and picture classification. There is a big gap between men and women on social arithmetic which shows 12 questions of comparison. By considering mathematical basic test differentiation, we gain output Independent Samples Test Test value of Asymp. Sig. (2-tailed) $=0,008<0,05$. Meaning that $\mathrm{H} 0$ means there is a difference in basic mathematical abilities between men and women.

\section{Acknowledgments}

The author would like to thank all elements and related parties for completing this research and article. The author would like to thank LPPM Yogyakarta PGRI University for providing research grant funds and also providing facilities and infrastructure during this research.

\section{References}

[1] D. A. Istikomah and P. Jana, "Mathematical Prolem Solving Ability in Apos Modified Learning Model ( M-APOS )," J. Phys. Conf. Ser., vol. 1254, no. 2019, pp. 1-6, 2019.

[2] R. Johar, "Domain Soal PISA untuk Literasi Matematika,” J. Peluang, vol. 1, no. 1, pp. 30-41, 2012.

[3] B. Hudiono, "Peran Pembelajaran Diskursus Multi Representasi Terhadap Pengembangan Kemampuan Matematika Dan Daya Representasi Pada Siswa SLTP,” J. Cakrawala Kependidikan, vol. 8, no. 2, pp. 101-203, 2010.

[4] M. M. Chusni, "Pengaruh Kemampuan Dasar Matematika Dan Kemampuan Penalaran Terhadap Hasil 
Belajar IPA/Fisika Pada Peserta Didik Kelas VII SMP Muhamadiyah Muntilan, Kabupaten Magelang, Jawa Tengah,” Berk. Fis. Indones., vol. 9, no. 1, pp. 16-23, 2017.

[5] P. Firmanti, "Penalaran Siswa Laki-laki dan Perempuan dalam Proses Pembelajaran Matematika," Humanisama J. Gend. Stud., vol. 1, no. 2, pp. 73-85, 2017.

[6] M. Asis, N. Arsyad, and Alimudin, "Profil Kemampuan Spasial Dalam Menyelesaikan Masalah Geometri Siswa Yang Memiliki Kecerdasan Logis Matematis Tinggi Ditinjau Dari Perbedaan Gender," J. Daya Mat., vol. 3, no. 1, pp. 78-87, 2015.

[7] H. Mustafidah and D. Aryanto, "Fuzzy Inference Systems to Predict Student Learning Achievement Based on the National Exam, a Test of Academic Potential, and Learning Motivation," JUITA, vol. 2, no. 1, pp. 1-7, 2012.

[8] K. L. Purwanti, "Perbedaan Gender Terhadap Kemampuan Otak Kanan pada Siswa Kelas I," SAWWA, vol. 9, no. 1, pp. 107-122, 2013.

[9] Z. A. MZ, "Perspektif gender dalam pembelajaran matematika," Marwah, vol. 12, no. 1, pp. 14-31, 2013.

[10] K. E. Lestari and M. R. Yudhanegara, Penelitian Pendidikan Matematika. Bandung, Jawa Barat, Indonesia: PT Refika Aditama., 2015.

[11] A. Orton, Learning Mathematics: Issues, Theory. Great Britain: Redwood Books., 1992. 